\title{
Temporal evolution of continental lithospheric strength in actively deforming regions
}

\author{
Wayne Thatcher and Fred F. Pollitz, USGS, 345 Middlefield \\ Road, Menlo Park, California 94025-3591, USA
}

\begin{abstract}
It has been agreed for nearly a century that a strong, loadbearing outer layer of earth is required to support mountain ranges, transmit stresses to deform active regions, and store elastic strain to generate earthquakes. However, the depth and extent of this strong layer remain controversial. Here we use a variety of observations to infer the distribution of lithospheric strength in the active western United States from seismic to steady-state time scales. We use evidence from post-seismic transient and earthquake cycle deformation, reservoir loading, glacio-isostatic adjustment, and lithosphere isostatic adjustment to large surface and subsurface loads. The nearly perfectly elastic behavior of Earth's crust and mantle at the time scale of seismic wave propagation evolves to that of a strong, elastic crust and weak, ductile upper mantle lithosphere at both earthquake cycle (EC, $\sim 10^{\circ}$ to $10^{3} \mathrm{yr}$ ) and glacio-isostatic adjustment (GIA, $\sim 10^{3}$ to $10^{4} \mathrm{yr}$ ) time scales. Topography and gravity field correlations indicate that lithosphere isostatic adjustment (LIA) on $\sim 10^{6}-10^{7}$ yr time scales occurs with most lithospheric stress supported by an upper crust overlying a much weaker ductile substrate. These comparisons suggest that the upper mantle lithosphere is weaker than the crust at all time scales longer than seismic. In contrast, the lower crust has a chameleon-like behavior, strong at EC and GIA time scales and weak for LIA and steady-state deformation processes. The lower crust might even take on a third identity in regions of rapid crustal extension or continental collision, where anomalously high temperatures may lead to large-scale ductile flow in a lower crustal layer that is locally weaker than the upper mantle. Modeling of lithospheric processes in active regions thus cannot use a one-size-fits-all prescription of rheological layering (relation between applied stress and deformation as a function of depth) but must be tailored to the time scale and tectonic setting of the process being investigated.
\end{abstract}

\section{INTRODUCTION}

The existence and importance of the lithosphere-the mechanically strong outer layer comprising Earth's crust and uppermost mantle-has been recognized both before and since the plate tectonic revolution of the 1960s. Here we define strength as the maximum deviatoric stress the lithosphere supports at a given depth, with "strong" lithosphere maintaining stresses at $\geq 100$ MPa and "weak" lithosphere $\leq 10 \mathrm{MPa}$. Barrell (1914) first showed that topographic loads at Earth's surface were supported by a strong lithosphere overlying a buoyant, inviscid asthenosphere. Jeffreys (1932) (in Jeffreys, 1952, p. 185-200) demonstrated that the weight of great mountain ranges generates high stresses that require support by a strong elastic element in the crust. Gunn (1947) applied the ideas of Barrell to model the flexure of the crust produced by surface loads such as oceanic islands and mountain ranges. With the discoveries of plate tectonics, Elsasser (1969) realized that the lithosphere described in these pioneering studies was a natural means for "guiding" (i.e., transmitting) plate boundary driving and resisting stresses for long distances into plate interiors. In a series of papers published in the early 1970s, Walcott resuscitated the work of Gunn to initiate plate flexure studies on the continents and in the ocean basins and to interpret the results in a plate tectonic context (e.g., Walcott, 1970). Watts and colleagues (Watts et al., 1975, 1980; Watts, 1978) applied these methods systematically to ocean basins. They showed that the effective elastic thickness of the lithosphere (Te) correlates with plate age and maximum depth of earthquakes, which is consistent with the conventional thermal model of oceanic lithosphere that cools conductively and thickens as it is advected away from a mid-oceanic ridge. Many subsequent studies have used the gravitational signal or the surface deformation due to flexure of continental lithosphere to estimate $\mathrm{Te}$ in a wide range of settings (see Watts, 2001).

Rock mechanics results from the laboratory (Byerlee, 1978; Goetz and Evans, 1979; Brace and Kohlstedt, 1980) and from deep-level mines and borehole measurements (McGarr and Gay, 1978) provided evidence that the lithosphere was strong and elastic in the upper crust and increasingly ductile and ultimately weaker in the lower crust and upper mantle. For oceanic lithosphere, the derived strength profile was particularly simple, increasing linearly with depth due to frictional resistance to fault slip in the crust and uppermost mantle, then decreasing exponentially with increasing depth and temperature in the upper mantle. The conventional strength profile for the continental lithosphere was apparently more complexcontrolled by friction and increasing with depth in the upper crust, decreasing in a ductile lower crust, then increasing abruptly with compositional change at the Moho before subsequently decaying rapidly with depth in the upper mantle.

Work in the 1980s and 1990s provided support for the conventional strength profile for continental lithosphere but also raised troubling questions. The apparent location of earthquake hypocenters in the uppermost mantle beneath Tibet and elsewhere seemed to confirm the high strength of the lithospheric mantle under continents (e.g., Chen and Molnar, 1983) as well as beneath ocean basins, where mantle earthquakes had long been reliably identified (e.g., Watts, 1978). It was recognized that exhumed metamorphic core complexes represented mid-crustal rocks that had been pervasively deformed by ductile flow during crustal extension (e.g., Crittenden et al., 1980). This, as well as the suggestions that the mid-crust beneath the Tibetan Plateau was effectively fluid at sufficiently long time scales (Zhao and Morgan, 1985, 1987; Royden et al., 
1997), appeared to conform nicely with the iconic image of a low strength zone in the continental lower crust interposed between strong upper crust and strong upper mantle (i.e., the "jelly sandwich" model). Nonetheless, it was realized about the same time (e.g., Sibson, 1986) that at least in some regions, lower crust with more mafic composition would be considerably stronger than the quartzofeldspathic crust usually invoked in constructing strength profiles. Furthermore, careful analysis near plate boundaries of stress indicators such as surface heat flux (Lachenbruch and Sass, 1980; Wang et al., 1995) and earthquake fault plane solutions (Zoback et al., 1987; Wang and He, 1999), showed that the conventional strength profiles do not apply in those locations and that major faults are weaker than the blocks they bound. In addition, there has been a growing appreciation that small amounts of water have enormous influence on the ductile strength of crust and upper mantle minerals, allowing a wide range of permissible rheological strength profiles (e.g., Karato and Wu, 1993; Kohlstedt et al., 1995).

Long-standing arguments favoring the steady-state strength of the upper crust and weakness of the lower crust adjacent to the San Andreas fault system in western California (Lachenbruch and Sass, 1973; Lachenbruch, 1980) were also receiving increasing support. Gravity-topography admittance studies from the western United States obtained Te values of $\sim 5-15 \mathrm{~km}$, comparable to the thickness of the seismogenic upper crust throughout much of the active West (Lowry and Smith, 1995). Borehole stress measurements and related modeling suggested that much of the strength of the continental lithosphere resides in the upper crust (see results summarized in Townend and
Zoback, 2000). A change with depth in the fault plane solutions of the deepest crustal earthquakes on the San Andreas system also suggested that all earthquake-generating stresses reside in the upper crust (Bokelmann and Beroza, 2000).

Two recent GSA Today articles have taken contrasting stands on the strength of continental lithosphere. Jackson (2002), relying primarily on joint work with colleagues (e.g., McKenzie and Fairhead, 1997; Maggi et al., 2000a, 2000b) argued that the conventional profile (i.e., the jelly sandwich model) should be largely abandoned because (1) reinterpretation of gravity anomalies caused by flexural loads indicate the strength of continental lithosphere resides in the crust (usually the upper crust); and (2) reanalysis of previously identified mantle earthquakes using seismic waveform data shows that these events may actually be located in the lowermost crust. Burov and Watts (2006) disagreed with the revisionist interpretation of the gravity data (see also Watts, 2001, p. 214-221) and appealed to mechanical models of lithospheric deformation to defend the conventional profile and argue for significant upper mantle strength.

The purpose of this paper is to draw attention to the increasing body of work using observed transient deformation following large crustal earthquakes that complements strength estimates based on glacio-isostatic adjustment (GIA) and lithosphere isostatic adjustment (LIA) data. This evidence supports the strong crust-weak upper mantle rheological model for the continental lithosphere in actively deforming regions. Figure 1 shows our inferred temporal evolution of lithospheric strength. Briefly put, at the time scale of elastic wave propagation, the entire lithosphere is strong and elastic, but the upper mantle

\section{Seismic Wave Propagation \\ Postseismic Glacio-Isostatic Relaxation \\ Adjustment \\ Lithosphere Isostatic Adjustment}
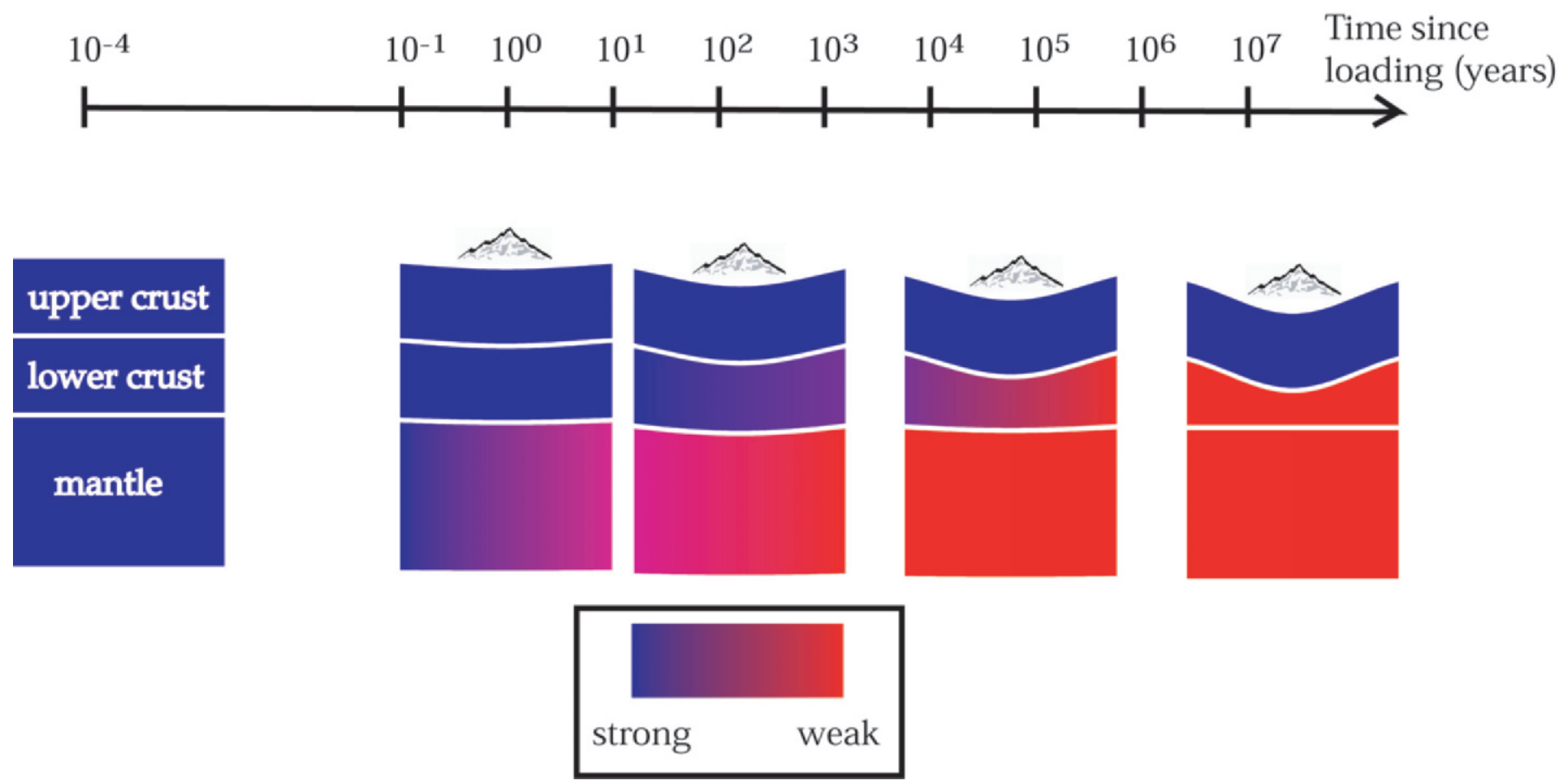

Figure 1. Evolution of strength in the crust and mantle of the western United States based on consideration of postseismic (PS) and glacio-isostatic adjustment (GIA) studies (Fig. 3) as well as topography and gravity (Lowry et al., 2000). The different time scales involved in lower crust and upper mantle weakening and the response to a surface load are shown. 
and lower crust progressively weaken with time until only the upper crust supports significant stresses at the $~ 1-10$ m.y. time scale of LIA. We propose Figure 1 as a working model to be critically evaluated, tested as new constraints on lithospheric strength become available, and appropriately modified, rejected, or accepted.

\section{POSTSEISMIC TRANSIENT DEFORMATION}

Conventional ground-based geodetic survey measurements have been applied since the 1970s to study postseismic (PS) deformation and infer lithospheric rheology (e.g., Nur and Mavko, 1974; Savage and Prescott, 1978; Thatcher et al., 1980; Thatcher and Rundle, 1984). However, over the past decade, new high-precision methods of space geodesy have greatly expanded the observational base and led to considerable refinement in our understanding of postseismic transient deformation and the processes controlling it. It is now recognized that post-earthquake deformation can be caused by (1) transient aseismic fault slip; (2) poroelastic relaxation due to fluid flow in the upper crust; and/or (3) viscoelastic relaxation in the lower crust and/or upper mantle. We confine our attention to postseismic deformation, where, in our view, the evidence is strong that the third process, viscoelastic relaxation through ductile flow, is the dominant process.

The essential features of the postseismic observations and the model used to explain them are shown in Figure 2. We consider the simplest case: two-dimensional earthquake faulting in an elastic layer of thickness $H$ overlying a viscoelastic half-space (Fig. 2A). The model can be generalized to include three dimensions and multiple layers in a spherical Earth (Pollitz, 1997). Coseismic fault slip produces a vertical displacement pattern like that shown for normal faulting in Figure 2B. Elastic stresses imposed in the underlying half-space at the time of the earthquake gradually relax by ductile flow, producing a spatial pattern of time-decaying vertical and horizontal displacement that scales with $H$ and with a temporal behavior that depends on the effective viscosity $\left(\eta_{\text {eff }}\right)$ of the underlying half-space. Observing first-order features in the space-time behavior of the post-earthquake deformation thus provides constraints on $H$ and on $\eta_{\text {eff }}$ in the lower crust and uppermost mantle.

PS deformation thus has many similarities to elastic plate flexure due to surface loads like mountains and seamounts, with the spatial wavelength of the deformation depending on the thickness (Te) of a strong, load-bearing elastic plate. However, in the PS problem, the load, due to stress redistribution caused by faulting, is small, inducing stress increments of only 1-10 MPa, a small fraction of the integrated lithosphere strength.

\section{RHEOLOGY THROUGH THE LENS OF TRANSIENT CRUSTAL DEFORMATION}

Figure 3 summarizes the lower crust and upper mantle viscosities inferred from PS relaxation provided by geodetic data. All determinations should be regarded as lower bounds because no PS data span time intervals longer than $40 \mathrm{yr}$, and there is a tendency for the effective viscosity to increase with time after the earthquake. The figure demonstrates that effective upper mantle viscosity $\eta_{\text {eff }}$ clusters near $3-4 \times 10^{18} \mathrm{~Pa} \mathrm{~s}$, and lower crust viscosity is generally $1-2 \times 10^{20} \mathrm{~Pa} s$ or greater. Even lower viscosities and smaller mantle relaxation times are suggested by the very rapid PS deformation observed after the Hector Mine earthquake (Pollitz et al., 2001; Pollitz, 2003; Freed and Bürgmann, 2004), consistent with a transient or power-law rheology (mantle $\eta_{\text {eff }}$ being initially very low, $\sim 10^{17} \mathrm{~Pa} s$, and increasing with time). The depth dependence of mantle viscosity inferred by Freed et al. (2007) suggests that the top 5-10 $\mathrm{km}$ of the mantle may have a much higher viscosity than the underlying mantle, as might be expected from the temperature dependence of viscosity (see Eq. 1). Figure 3 establishes nonetheless that at time scales up to $10^{2} \mathrm{yr}$, the upper mantle, perhaps below a thin, high-viscosity lid, has an effective viscosity $\sim 2$ orders of magnitude less than the lower crust.

Although best documented in the western United States, the picture of an effectively elastic lower crust and low-viscosity upper mantle is also obtained in other areas (Ergintav et al., 2006; Thatcher et al., 1980; Pollitz and Sacks, 1996; Hilley et al., 2005; Hu et al., 2004; Wang, 2007).
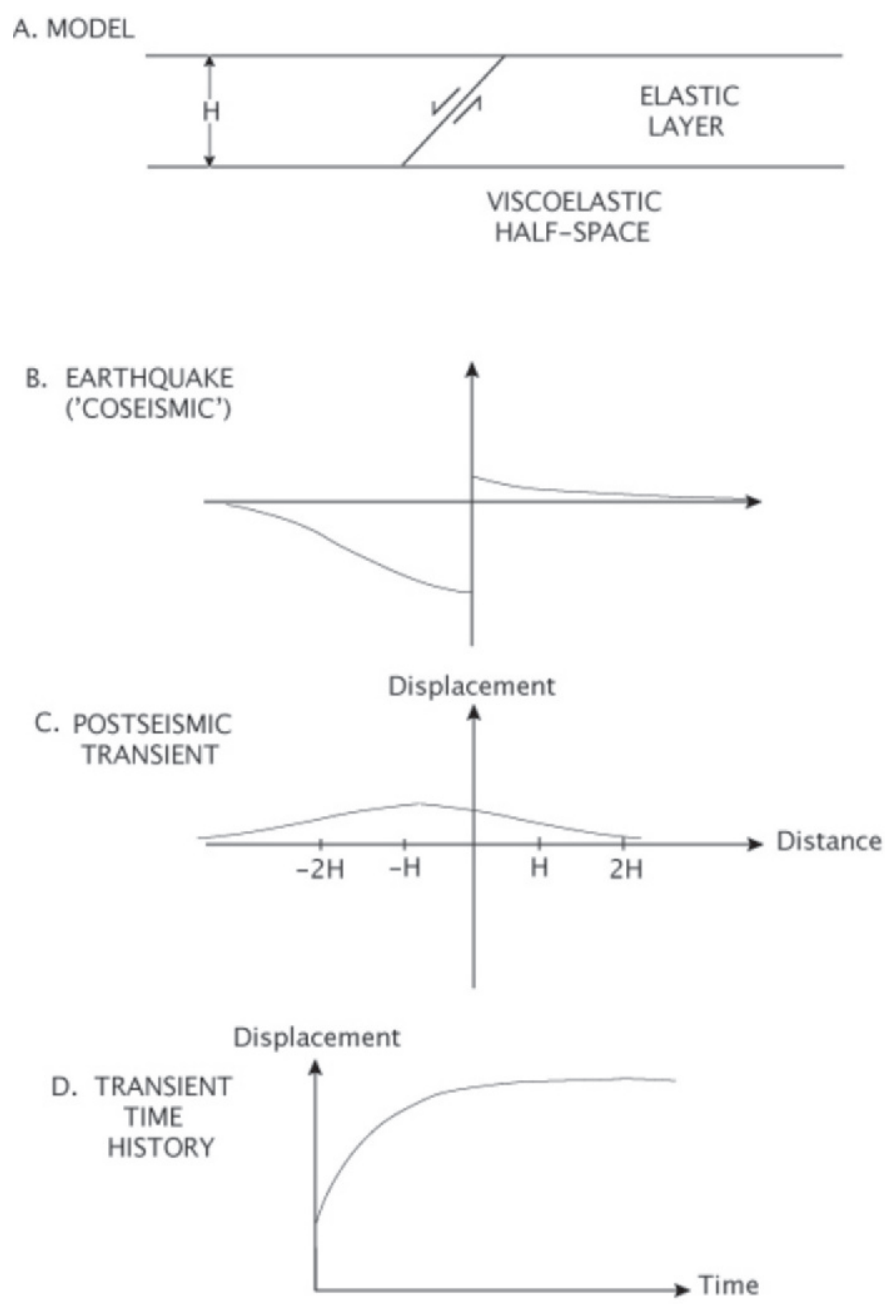

Figure 2. The earthquake cycle in an idealized continental model consisting of an elastic layer of thickness $H$ underlain by a viscoelastic half-space (A). Profiles at Earth's surface: (B) vertical displacement associated with the static displacement field of the earthquake, and (C) the accumulated displacement over a definite postseismic time interval. (D) Time dependence of surface displacement, including the abrupt offset at time 0 (just after the earthquake) and decaying postseismic velocity with increasing time. 


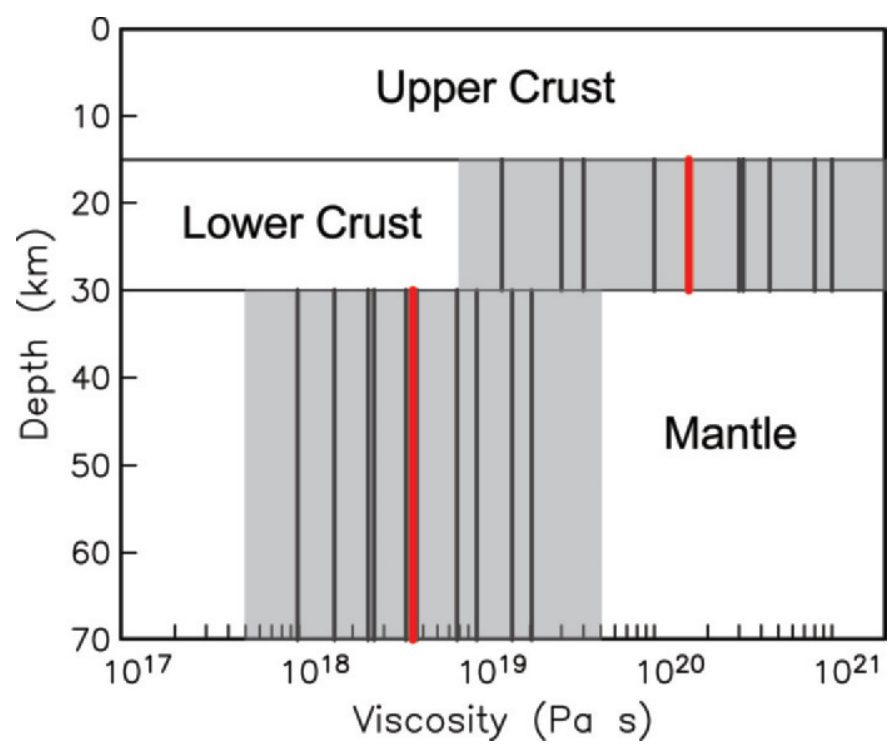

Figure 3. Summary of lower crust and upper mantle viscosities in the western United States estimated in crustal deformation studies of postseismic (and post-lake-filling) relaxation. Shaded areas bracket the complete range of estimated viscosities; vertical bars denote the mean viscosity obtained in an individual study. Red bars indicate the mean of all viscosity estimates in the respective lower crust and mantle regions. Because of the time scales involved $\left(\leq 10^{2} \mathrm{yr}\right)$, all estimates represent lower bounds on possible longer-term effective viscosity. Viscosity estimates of contributing studies (Kaufmann and Amelung, 2000; Pollitz et al., 2000; Nishimura and Thatcher, 2003; Pollitz, 2003; Freed and Bürgmann, 2004; Gourmelen and Amelung, 2005; Chang and Smith, 2005; W.C. Hammond, 2007, personal commun.) are tabulated in Bürgmann and Dresen (2008) and W.C. Hammond (2007, personal commun.). Most viscosity estimates are based on a Newtonian rheology. Exceptions are Pollitz (2003), which uses a Burgers body for the upper mantle, and Freed and Bürgmann (2004), which uses a nonlinear rheology (Eq. 1 with $n=$ 3.5); a range of $\eta_{\text {eff }}$ is used to represent the Freed and Bürgmann (2004) model. Both the lower crust and upper mantle are schematically depicted with respective uniform viscosities - a simplification-though most studies have indeed assumed uniform viscosity in each domain.

\section{ENDMEMBER FLOW PROFILES}

Creep curves determined in laboratory experiments on numerous crustal and mantle materials generally yield steadystate flow laws of the form (e.g., Ranalli, 1995)

$$
\dot{\varepsilon}=A \sigma^{n} \exp [-(Q+P V) / R T]
$$

where $A$ is a material constant, $\dot{\varepsilon}$ is the strain rate, $\sigma$ is differential stress needed to deform the material at this strain rate, $Q$ and $V$ are the activation energy and volume, respectively, $P$ is pressure, $T$ is absolute temperature, $R$ is the gas constant, and $n$ is the stress exponent. More generally, we can write $\sigma=2 \eta_{\text {eff }} \dot{\varepsilon}$, so that at a given strain rate, the differential stress increases with increasing effective viscosity $\eta_{\text {eff. }}$ We define this differential stress as the ductile strength (or simply "strength") of the material. It then follows that the viscosity profile in Figure 3 implies that the lower crust is much stronger than the upper mantle in the western United States.

The rheology is linear (Newtonian) when $n=1$ and nonlinear when $n \neq 1$. As expected from the temperature dependence of Equation 1, experiments for thermally activated creep show that all constituent minerals of the lower crust (including quartz, plagioclase, and phyllosilicates) and upper mantle (olivine, pyroxenes, and garnet) are weaker the higher the temperature. Water weakening of quartz and olivine indicates that crust and mantle rocks are also sensitive to water content (e.g., Mackwell et al., 1985; Gleason and Tullis, 1995). Figure 4 summarizes the expected viscosities of representative rock types in the lower crust and upper mantle at typical tectonic strain rates $\left(10^{-14}-10^{-13} \mathrm{~s}^{-1}\right)$ for a geotherm considered representative of the western United States on average.

Mineral assemblages other than quartz are likely to be more representative of the lower crust (Sibson, 1986); a range of observations suggests that wet olivine may be more representative of the upper mantle in tectonically active areas (Pollitz et al., 2000; Dixon et al., 2004; Hyndman et al., 2005). These choices would result in a substantially stronger lower crust and weaker upper mantle (Fig. 4), consistent with the inferred effective viscosity or strength in the western United States (Fig. 3). An excellent recent review by Bürgmann and Dresen (2008) discusses these issues in greater depth.

\section{TIME-DEPENDENT LITHOSPHERIC STRENGTH}

Deformation observed in the $1-10$ yr after major earthquakes occurs with increasingly longer time constants, suggesting that as stresses relax and strain rates decline the effective viscosity increases. Given that the viscosities obtained from PS relaxation shown in Figure 3 are the lower bounds, the lower crust may be effectively elastic over the time scale of the earthquake cycle $\left(\sim 10^{2}\right.$ to $\left.10^{3} \mathrm{yr}\right)$, so any time-dependence in effective viscosity would then be undetectable.

Assuming that both lower crust and mantle viscosity continue to increase with time even beyond PS time scales, both consequently undergo a gradual loss of strength. How rapidly do the lower crust and uppermost mantle evolve to a state of lower strength? Two lines of evidence support the strong crustweak upper mantle model.

First, constraints derived from GIA studies apply over time scales of $\sim 10^{3}-10^{4} \mathrm{yr}$. In the western United States, these include removal of surface loads at the end of the last ice age, ca. 15 ka B.P.; surface uplift that followed draining of pluvial Lake Bonneville and Lake Lahontan in the Basin and Range Province (Bills et al., 1994, 2007); and flexural rebound of Puget Sound on removal of its glacial load (James et al., 2000). Given the available lower bounds on lower crustal viscosity from the PS studies ( $10^{20}-10^{21} \mathrm{~Pa}$ s; see Fig. 3), it might be expected that the lower crust would have relaxed over GIA time scales. On the contrary: the GIA studies independently suggest essentially the same rheological layering as shown in Figure 3, indicating a strong elastic upper crust, a high-viscosity, effectively elastic lower crust and a weaker upper mantle.

Second, the relation between topography and the gravity field in the western United States provides constraints on lithospheric rheology over the time scales of lithospheric adjustment to large surface and subsurface loads that may reflect its steady-state strength. The time scale over which LIA equilibrium is achieved is not well known but may be in the range $\sim 10^{6}-10^{7}$ yr. Figure 5, modified from Lowry et al. (2000), maps the spatial distribution of effective elastic thickness (Te) derived in this way. It also shows sites where PS and GIA studies have constrained rheology 

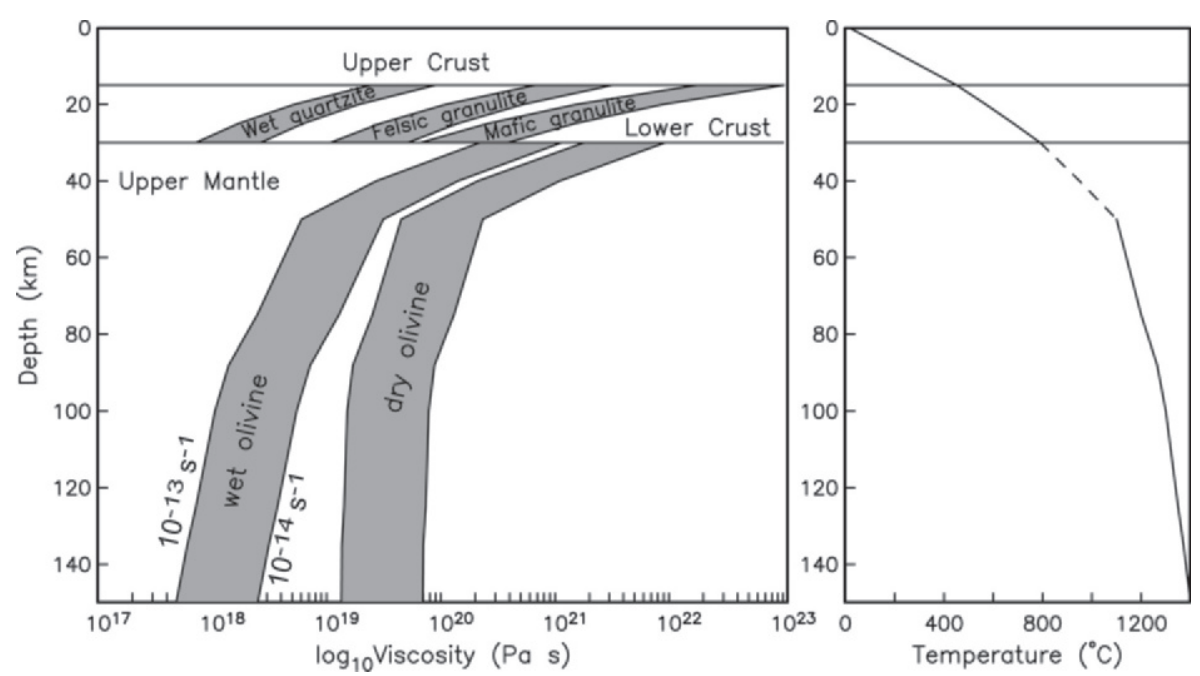

Figure 4. Range of depth-dependent effective viscosity of lower crust and mantle materials at strain rates between $10^{-14} / \mathrm{s}$ and $10^{-13} / \mathrm{s}$; lowest viscosities correspond to the larger strain rate, as indicated for wet olivine. Mantle viscosity curves are given by Dixon et al. (2004; Eq. 1 therein; their $\eta_{\text {eff }}$ is divided by two here), with material constants for wet and dry olivine provided in their Table 2 and the mantle temperature profile given in their Table 3. In the crust, the geotherm is prescribed by Afonso and Ranalli (2004; Eq. 3 and Table 2 therein), with a surface heat flow of $70 \mathrm{~mW} / \mathrm{m}^{2}$ and Moho depth of $30 \mathrm{~km}$. Lower crust viscosity curves are based on material constants for wet quartzite (Kirby and Kronenberg, 1987), felsic granulite, and mafic granulite (Wilks and Carter, 1990). The jelly sandwich model is represented by the combination of wet quartzite for the lower crust and dry olivine for the upper mantle.

in the crust and uppermost mantle. As maps of surface heat flux show (e.g., Sass et al., 1989), much of the Te variation in the western United States shown in Figure 5 is directly related to the thermal regime and the depth of the brittle-ductile transition in the crust. Note also that $T e$ is systematically greater to the east, consistent with the lower surface heat flux and cooler crust in the central and eastern United States. It is clear from this map that $T e$ is $\sim 5-15 \mathrm{~km}$ over much of the active West, considerably less than the crustal thickness. The most straightforward interpretation of these results and those discussed above is that lower crust and upper mantle stresses maintained over PS and GIA time scales relax by ductile flow at greater (LIA) times and that lithospheric stress is supported by the seismogenic upper crust alone.

\section{CHAMELEON LOWER CRUST}

In contrast to the consistent weakness of the mantle beneath plate boundary zones at both shorter $\left(10^{0}\right.$ to $\left.10^{4} \mathrm{yr}\right)$ and longer $\left(\geq 10^{6} \mathrm{yr}\right)$ time scales, the lower crust appears to exhibit different behavior at different time scales and in thermally extreme tectonic settings. At PS and GIA time scales, the lower crust is strong, and its behavior is essentially elastic. For $\sim 10^{6} \mathrm{yr}$ and longer after load application, the lower crust relaxes and is effectively inviscid. At earthquake cycle time scales $\left(10^{2}-10^{3} \mathrm{yr}\right.$ repeat time of major earthquakes), the lower crust may behave essentially like the upper crust, with narrow weak zones of concentrated shear separating stronger, nearly elastic blocks.

It may seem paradoxical that although the lower crust is strong and nearly elastic at time scales $\leq 10^{4} \mathrm{yr}$, it is essentially devoid of even small earthquakes. However, this behavior can be understood if earthquake fault slip requires significant ambient stress levels and the lower crust is weak at long time scales. The absence of earthquake-generating stresses in the lower crust is expected if this region is weak at long time scales and does not support significant steady-state stress, as suggested by the small Te values determined for much of the western United States (Fig. 5). A transition from strong upper crust to weak lower crust is also supported by consistent changes with depth in the fault plane solutions of the deepest upper crustal earthquakes occurring along the San Andreas fault system in California. Bokelmann and Beroza (2000) show that inferred principal stress axes of these small earthquakes imply a transition from high to low ambient stress at the seismic-aseismic transition depth ( 15 km in California), consistent with negligible long-term strength of the lower crust.

The lower crust may also be weak at shorter time scales due to special thermal conditions not found in most active regions (e.g., Pollitz et al., 2001; McKenzie and Jackson, 2002). In highly extended terranes, the observation of an essentially flat Moho (e.g., McCarthy et al., 1991) suggests pervasive bulk ductile flow of the lower crust. Likewise, the very flat topography of the Tibetan Plateau and the contrasting topographic gradients at its north, east, and southeast margins suggests lower crustal flow over large distances in this region (Zhao and Morgan, 1987; Clark and Royden, 2000). Topography created in continental collision zones is accompanied by crustal thickening, with lower crustal rocks at twice their typical depths. The higher temperatures encountered below $\sim 40$ $\mathrm{km}$ are expected to lead to anomalously low crustal strength at these depths.

\section{FIELD AND LABORATORY CONSTRAINTS}

Field observations and laboratory experiments bearing on rheology of the ductile lithosphere each have strengths and limitations. Field observations of lithospheric loading due to earthquakes, ice sheets, and tectonic-magmatic topography represent direct experiments on earth materials at true scale and strain rate. Loads are known, but rheological layering and its lateral variations must be inferred (nonuniquely) from inevitably limited measurements made at Earth's surface. Finally, the composition and state of lithospheric rocks is imperfectly known.

In contrast, laboratory experiments on ductile flow are carried out on known materials, directly observe the micromechanical nature of ductile shearing, and determine rheological laws at pressures, temperatures, and compositions thought to prevail in Earth's lithosphere. However, lab experiments are typically carried out at length scales $\sim 8$ orders of magnitude smaller and strain rates $\sim 4-8$ orders of magnitude faster than deformation processes occurring in the earth.

Given these contrasting strengths and limitations, it is increasingly being recognized that the role of field observations is 

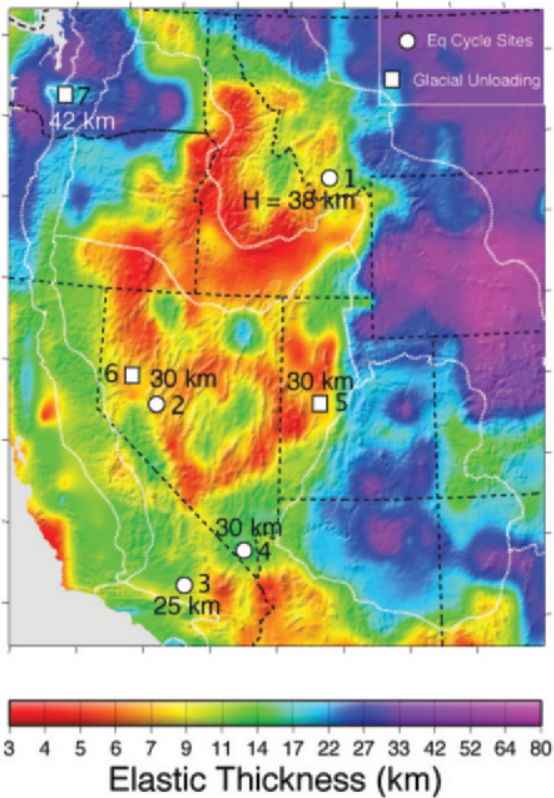

Figure 5. Effective elastic thickness $T e$ in the western United States (Lowry et al., 2000) and the locations of crustal deformation sources that yield estimates of lower crust and upper mantle viscosity. Sites where PS and GIA constraints on crust and upper mantle rheology have been obtained are shown by white circles (PS) and squares (GIA). 1-Hebgen Lake, Montana (Nishimura and Thatcher, 2003); 2-Central Nevada Seismic Belt (W.C. Hammond, 2007 personal commun.); 3-Hector Mine, California (Pollitz et al., 2001); 4-Lake Mead, Arizona (Kaufmann and Amelung, 2000); 5-Lake Bonneville, Utah (Bills et al., 1994); 6-Lake Lahontan, Nevada (Bills et al., 2007); 7-Puget Sound, Washington (James et al., 2000). In all these cases, the effective elastic layer thickness $H$ (values given beside each locality) is comparable to the crustal thickness of $\sim 30$ $\mathrm{km}$, considerably greater than the $T e$ obtained from the topography-gravity shown here.

to discriminate among the many possible rheologies for the lithosphere determined by laboratory experiments. For example, the growing evidence that upper mantle lithosphere is weak in at least some geologic settings has led to suggestions (e.g., Dixon et al., 2004; Hyndman et al., 2005; Jackson, 2002; Maggi et al., 2000a; Pollitz et al., 2000) that upper mantle rocks are hydrated by subduction magmatic processes and deform according to power law flow appropriate for wet olivine determined in the lab (e.g., Karato and Wu, 1993; Hirth and Kohlstedt, 1996). In the same spirit, we can appeal to laboratory results to rationalize the temporal evolution of strength of the lower crust. We suggest that the temporal transition from elastic to roughly inviscid behavior follows if lower crustal effective viscosity (which could be either power law or linear) is relatively high ( $>10^{21} \mathrm{~Pa} \mathrm{~s}$ ), consistent with a mafic granulite composition (Fig. 4). In this case, little deformation occurs at PS and GIA time scales, but stresses relax at longer times.

PS and GIA processes in tectonically active regions involve application of impulsive loads that lead to transient ductile flow superimposed on the steady-state background deformation caused by plate driving and resisting forces and internal lithospheric buoyancy. At present, we know of no definitive evidence from laboratory or field studies that would permit us to determine whether the transient and steady-state deformation mechanisms are identical. However, transient loading of the lithosphere (i.e., PS and GIA loads) and steady-state adjustment of the lithosphere to topographic loads (i.e., LIA loads) both require a weak upper mantle. This strongly suggests to us that, regardless of deformation mechanism, this weakness is a robust feature of tectonically active regions.

\section{DISCUSSION}

Modeling of active deformation must take into account the rheological layering appropriate to the process being considered. At earthquake cycle and GIA time scales, the entire crust is strong and elastic and deformation is accommodated on faults and ductile shear zones, while the upper mantle is viscously coupled to the overlying crust but much weaker. Postseismic observations indicate that the upper mantle is strong (and its effective viscosity low) immediately following a large earthquake, when strain rates are high. Its strength decreases sharply (and effective viscosity increases) with time as strain rates decline, and the interseismic strength is much less than that of the lower crust. At the time scales of isostatic compensation, the upper crust carries most of the lithospheric strength and the lower crust and uppermost mantle are effectively inviscid. For the steady-state conditions appropriate for modeling lithospheric dynamics and deformation, the upper crust is strong and elastic except where cut by weak faults, and it is viscously coupled to the lower crust and upper mantle.

While the model of lithospheric strength presented here refers only to data from active regions, there is some evidence that the temporal evolution of strength we infer may also be appropriate for cratonic lithosphere. Milne et al. (2001) used present-day measurements of vertical and horizontal deformation from a 33-station continuous GPS network in Fennoscandia to propose a GIA model with a 120 -km-thick elastic layer (95\% confidence interval $90-170 \mathrm{~km}$ ) overlying an upper mantle of viscosity $0.5-1.0 \times 10^{21} \mathrm{~Pa}$ s. On the other hand, Poudjom-Djomani et al. (1999) have applied the gravity-topography coherence method in the same region to estimate Te ranging from 10 to $70 \mathrm{~km}(10-40 \mathrm{~km}$ at all but a few of the GPS sites used by Milne et al. [2001] in their analysis). The difference between the two estimates is independent of the ongoing dispute over the proper analysis of gravity and topography data (McKenzie and Fairhead, 1997; Watts, 2001; Burov and Watts, 2006). Although PoudjomDjomani et al. (1999) used the Bouguer coherence method criticized by McKenzie and Fairhead (1997), application of the free air coherence method preferred by McKenzie and Fairhead (1997) generally produces even smaller Te values in cratonic regions. Comparison of the GIA and LIA results suggests a strong upper crust and upper mantle lithosphere at GIA time scales but lithospheric stresses supported largely or exclusively within the cratonic crust at longer times.

Our conclusions differ from those of Burov and Watts (2006), who argue for a strong upper mantle lithosphere based on their modeling of long-term active tectonic deformation at lithospheric scales. In our view, their strongest argument is that high-strength upper mantle lithosphere is required to prevent its advective removal and descent into the deeper mantle, which would juxtapose hot asthenosphere at the base of the crust and result in an inadmissibly high heat flux at Earth's surface in many regions. Perhaps upper mantle lithosphere in active regions is weak enough to deform readily but just strong enough to support its own weight, perhaps through a finite yield stress condition that is not formally included in ductile flow laws like those given by Equation 1. Beyond this speculation, we have no ready explanation for the incompatibility of our inferences and the Burov-Watts modeling results. 
We do worry, however, that literal acceptance of the laboratory rheologies used in their modeling, particularly for long time scales and low strain rates, may not be justified and suggest that the more direct observations bearing on lithospheric strength described here should be accorded more weight.

\section{SUMMARY AND CONCLUSIONS}

We appeal to three types of crustal loading to propose a working model of continental lithospheric strength valid from $\sim 1$ yr to million-year time scales in actively deforming regions (Fig. 1). Results of observations and simple models imply a strong crust-weak mantle lithosphere at PS and GIA time scales. For GIA and steady-state deformation processes, available data suggest a strong upper crust overlying a much weaker lower crust and upper mantle.

Our working model is consistent with first-order observations and has the advantage of simplicity. It is based on observations and simple models of elastic flexure and ductile flow and accounts for lithospheric strength from earthquake cycle to steady-state time scales. It does not depend upon large extrapolations in length- and time-scales between laboratory-derived flow laws and real earth deformation processes.

However, our proposed model has several shortcomings and raises unanswered questions. Observations have limited depth resolution and cannot exclude the possible existence of a thin upper mantle lid that is strong at PS and GIA time scales. Also, inferences of lithospheric strength at LIA time scales may be affected by non-elastic processes in highly flexed crust near faults (especially normal faults in extended terranes; see Hassani and Chéry, 1996), leading to underestimates of true elastic plate thickness. Furthermore, our model does not constrain the actual micromechanical mechanisms responsible for ductile deformation of the lower crust and upper mantle lithosphere. For example, low strain and stress increment PS and GIA transient loading may induce flow via a different micromechanical mechanism than that governing steady-state flow due to large loads (and hence larger strains and stresses) occurring at LIA and longer time scales. On the other hand, this uncertainty does not limit the applicability of our inferred strength distributions at the time scales appropriate to PS, GIA, and LIA processes, and our conclusions do not depend strongly on the ductile flow laws appropriate for lower crust and upper mantle lithosphere.

\section{ACKNOWLEDGMENTS}

We thank R. Bürgmann, W. Hammond, and L. Hearn for sharing preliminary drafts of their work with us. Careful reviews by B. Bills, R. Bürgmann, J. Chéry, T.C. Hanks, A.H. Lachenbruch, J.C. Savage, R.S. Stein, and K. Wang resulted in considerable improvements to the manuscript. A.R. Lowry kindly supplied the base map from Lowry et al. (2000) used in Figure 5.

\section{REFERENCES CITED}

Afonso, J.C., and Ranalli, G., 2004, Crustal and mantle strengths in continental lithosphere: Is the jelly sandwich model obsolete?: Tectonophysics, v. 394 p. 221-232, doi: 10.1016/j.tecto.2004.08.006.

Barrell, J., 1914, The strength of Earth's crust, part viii. Physical conditions controlling the nature of lithosphere and asthenosphere: The Journal of Geology, v. 22, p. $425-443$.

Bills, B.G., Adams, K.D., and Wesnousky, S.G., 2007, Viscosity structure of the crust and upper mantle in western Nevada from isostatic rebound patterns of the late Pleistocene Lake Lahontan high shoreline: Journal of Geophysical Research, v. 102, doi: 10.1029/2005JB003941.
Bills, B.G., Currey, D.R., and Marshall, G.A., 1994, Viscosity estimates for the crust and upper mantle from patterns of lacustrine shoreline deformation in the Eastern Great Basin: Journal of Geophysical Research, v. 99, p. 22,059-22,086, doi: 10.1029/94JB01192.

Bokelmann, G.H.R., and Beroza, G.C., 2000, Depth-dependent earthquake focal mechanism orientation: Evidence for a weak zone in the lower crust: Journal of Geophysical Research, v. 105, p. 21,683-21,696, doi: 10.1029/2000JB900205.

Brace, W.F., and Kohlstedt, D.L., 1980, Limits on lithospheric stress imposed by laboratory experiments: Journal of Geophysical Research, v. 85, p. 6248-6252, doi: 10.1029/JB085iB11p06248.

Bürgmann, R., and Dresen, G., 2008, Rheology of the lower crust and upper mantle: Evidence from rock mechanics, geodesy, and field observations: Annual Review of Earth and Planetary Sciences, v. 36, doi: 10.1146/annurev. earth.36.031207.124326.

Burov, E.B., and Watts, A.B., 2006, The long-term strength of continental lithosphere: "jelly sandwich" or "crème brûlée"?: GSA Today, v. 16, no. 1, p. 4-10, doi: 10.1130/1052-5173(2006)016<4:TLTSOC>2.0.CO;2

Byerlee, J.D., 1978, The friction of rocks: Pure and App.lied Geophysics, v. 116 p. 615-626, doi: 10.1007/BF00876528.

Chang, W.-L., and Smith, R.B., 2005, Lithospheric rheology from postseismic deformation of a $M=7.5$ normal-faulting earthquake with implications for continental kinematics [Abs. 225-4]: Geological Society of America Abstracts with Programs, v. 37, no. 7, p. 497

Chen, W.-P., and Molnar, P., 1983, Focal depths of intracontinental and intraplate earthquakes and their implications for the thermal and mechanical properties of the lithosphere: Journal of Geophysical Research, v. 88, p. 4183-4214, doi: 10.1029/JB088iB05p04183.

Clark, M.K., and Royden, L.H., 2000, Topographic ooze: Building the eastern margin of Tibet by lower crustal flow: Geology, v. 28, p. 703-706, doi: 10.1130/00917613(2000) $28<703$ :TOBTEM $>2.0$. CO;2.

Crittenden, M.D., Jr., Coney, P.J., and Davis, G.H., 1980, Cordilleran metamorphic core complexes: Geological Society of America Memoir 153, 490 p.

Dixon, J.E., Dixon, T.H., Bell, D.R., and Malservisi, R., 2004, Lateral variation in upper mantle viscosity: Role of water: Earth and Planetary Science Letters, v. 222, p. 451-467, doi: 10.1016/j.epsl.2004.03.022.

Elsasser, W.M., 1969, Convection and stress propagation in the upper mantle, in Runcorn, S.K., ed., The application of modern physics to the earth and planetary interiors: Hoboken, New Jersey, John Wiley, p. 223-246.

Ergintav, S., McClusky, S., Hearn, E., and Reilinger, R., 2006, Postseismic deformation following the 1999 Izmit, Turkey, earthquake: The first seven years: Eos (Transactions, American Geophysical Union), v. 87, no. 52, Fall Meeting Supplement, Abstract G32A-02.

Freed, A.M., and Bürgmann, R., 2004, Evidence of power law flow in the Mojave Desert mantle: Nature, v. 430, p. 548-551, doi: 10.1038/nature02784.

Freed, A.M., Bürgmann, R., and Herring, T., 2007, Far-reaching transient motions after Mojave earthquakes require broad mantle flow beneath a strong crust: Geophysical Research Letters, v. 34, L19392, doi: 10.1029/2007GL030959.

Gleason, G.C., and Tullis, J., 1995, A flow law for dislocation creep of quartz aggregates determined with the molten salt cell: Tectonophysics, v. 247, p. 1-23, doi: 10.1016/0040-1951(95)00011-B.

Goetz, C., and Evans, B., 1979, Stress and temperature in the bending lithosphere as constrained by experimental rock mechanics: Geophysical Journal of the Royal Astronomical Society, v. 59, p. 463-478.

Gourmelen, N., and Amelung, F., 2005, Postseismic mantle relaxation in the Central Nevada Seismic Belt: Science, v. 310, p. 1473-1476, doi: 10.1126/ science. 1119798.

Gunn, R., 1947, Quantitative aspects of juxtaposed ocean deeps, mountain chains, and volcanic ranges: Geophysics, v. 12, p. 238-255, doi: 10.1190/1.1437321.

Hassani, R., and Chéry, J., 1996, Anelasticity explains topography associated with Basin and Range normal faulting: Geology, v. 24, p. 1095-1098, doi: 10.1130/ 0091-7613(1996)024<1095:AETAWB >2.3.CO;2.

Hilley, G.E., Bürgmann, R., Zhang, P.-Z., and Molnar, P., 2005, Bayesian inference of plastosphere viscosities near the Kunlun Fault, northern Tibet: Geophysical Research Letters, v. 32, p. L01302, doi: 10.1029/2004GL021658

Hirth, G, and Kohlstedt, D.L 1996, Water in the oceanic upper mantle: Implications for rheology, melt extraction, and the evolution of the lithosphere: Earth and Planetary Science Letters, v. 144, p. 93-108, doi: 10.1016/0012-821X(96)00154-9.

Hu, Y., Wang, K., He, J., Klotz, J., and Khazaradze, G., 2004, Three-dimensional viscoelastic finite element model for postseismic deformation of the great 1960 Chile earthquake: Journal of Geophysical Research, v. 109, doi: 10.1029/2004JB003163.

Hyndman, R.D., Currie, C.A., and Mazzotti, S.P., 2005, Subduction zone backarcs, mobile belts, and orogenic heat: GSA Today, v. 5, no. 2, p. 4-10.

Jackson, J., 2002, Strength of the continental lithosphere: Time to abandon the jelly sandwich?: GSA Today, v. 12, p. 4-10, doi: 10.1130/1052-5173(2002)012 $<0004$ :SOTCLT>2.0.CO;2.

James, T.S., Clague, J.J., Wang, K., and Hutchinson, I., 2000, Postglacial rebound at the northern Cascadia subduction zone: Quaternary Science Reviews, v. 19, p. 1527-1541, doi: 10.1016/S0277-3791(00)00076-7.

leffreys, H., 1932, On the stresses in the Earth's crust required to support surface inequalities: Monthly Notes of the Royal Astronomical Society, Geophys. v. 3, Suppl., p. 60-69. 
Jeffreys, H., 1952, The Earth, its origin, history, and physical constitution, 3rd edition: Cambridge, Cambridge University Press, 392 p.

Karato, S.-I., and Wu, P., 1993, Rheology of the upper mantle: A synthesis: Science, v. 260, p. 771-778, doi: 10.1126/science.260.5109.771

Kaufmann, G., and Amelung, F., 2000, Reservoir-induced deformation and continental rheology in the vicinity of Lake Mead, Nevada: Journal of Geophysical Research, v. 105, p. 16,341-16,358, doi: 10.1029/2000JB900079.

Kirby, S.H., and Kronenberg, A.K., 1987, Strength of the lithosphere: Selected topics: Reviews of Geophysics, v. 25, p. 1219-1244, doi: 10.1029/ RG025i006p01219.

Kohlstedt, D.L., Evans, B., and Mackwell, S.J., 1995, Strength of the lithosphere-constraints imposed by laboratory experiments: Journal of Geophysical Research, v. 100, p. 17,587-17,602, doi: 10.1029/95JB01460.

Lachenbruch, A.H., 1980, Frictional heating, fluid pressure, and the resistance to fault motion: Journal of Geophysical Research, v. 85, p. 6097-6112, doi: 10.1029/ JB085iB11p06097.

Lachenbruch, A.H., and Sass, J., 1973, Thermo-mechanical aspects of the San Andreas, in Kovach, R. and Nur, A., eds., Proceedings of the Conference on the Tectonic Problems of the San Andreas Fault System: Palo Alto, California Stanford University Press, p. 192-205.

Lachenbruch, A.H., and Sass, J.H., 1980, Heat flow and energetics of the San Andreas fault zone: Journal of Geophysical Research, v. 85, p. 6185-6223, doi: 10.1029/ JB085iB11p06185.

Lowry, A.R., and Smith, R.B., 1995, Strength and rheology of the western U.S Cordillera: Journal of Geophysical Research, v. 100, p. 17,947-17,963, doi: 10.1029/95JB00747.

Lowry, A.R., Ribe, N.M., and Smith, R.B., 2000, Dynamic elevation of the Cordillera, western United States: Journal of Geophysical Research, v. 105 p. 23,371-23,390, doi: 10.1029/2000JB900182

Mackwell, S.J., Kohlstedt, D.L., and Paterson, M.S., 1985, Role of water in the deformation of olivine single crystals: Journal of Geophysical Research, v. 90, p. 11,319-11,333.

Maggi, A., Jackson, J.A., McKenzie, D., and Priestly, K., 2000a, Earthquake foca depths, effective elastic thickness, and the strength of the continental lithosphere: Geology, v. 28, p. 495-498, doi: 10.1130/0091-7613(2000)28<495: EFDEET>2.0.CO;2.

Maggi, A., Jackson, J.A., Priestly, K., and Baker, C., 2000b, A reassessment of foca depth distributions in southern Iran, the Tien Shan and northern India: Do earthquakes occur in the continental mantle?: Geophysical Journal International, v. 143, p. 629-661, doi: 10.1046/j.1365-246X.2000.00254.x.

McCarthy, J., Larkin, S.P., Fuis, G.S., Simpson, R.W., and Howard, K.A., 1991 , Anatomy of a metamorphic core complex: Seismic refraction/wide-angle reflection profiling in southeastern California and western Arizona: Journal of Geophysical Research, v. 96, p. 12,259-12,291, doi: 10.1029/91JB01004

McGarr, A., and Gay, N.C., 1978, State of stress in the earth's crust: Annual Review of Earth and Planetary Sciences, v. 6, p. 405-436, doi: 10.1146/annurev. ea.06.050178.002201.

McKenzie, D.P., and Fairhead, D., 1997, Estimates of the effective elastic thickness of the continental lithosphere from Bouguer and free-air gravity anomalies: Journal of Geophysical Research, v. 102, p. 27,523-27,552, doi: 10.1029/97JB02481.

McKenzie, D.P., and Jackson, J.A., 2002, Conditions for flow in the continental crust: Tectonics, v. 21, p. 1055, doi: 10.1029/2002TC001394

Milne, G.A., Davis, J.L., Mitrovica, J.X., Scherneck, H.-G., Johansson, J.M., Vermeer, M., and Koivula, H., 2001, Space-geodetic constraints on glacial isostatic adjustment in Fennoscandia: Science, v. 291, p. 2381-2385, doi: 10.1126/ science. 1057022

Nishimura, T., and Thatcher, W., 2003, Rheology of the lithosphere inferred from postseismic uplift following the 1959 Hebgen Lake earthquake: Journal of Geophysical Research, v. 108, no. B8, 2389, doi: 10.1029/2002JB002191.

Nur, A., and Mavko, G., 1974, Postseismic viscoelastic rebound: Science, v. 183 p. 204-206, doi: 10.1126/science.183.4121.204.

Pollitz, F.F., 1997, Gravitational viscoelastic postseismic relaxation on a layered spherical Earth: Journal of Geophysical Research, v. 102, p. 17,921-17,941, doi: $10.1029 / 97 J$ J01277.

Pollitz, F.F., 2003, Transient rheology of the uppermost mantle beneath the Mojave Desert, California: Earth and Planetary Science Letters, v. 215, p. 89-104, doi: 10.1016/S0012-821X(03)00432-1.

Pollitz, F.F., and Sacks, I.S., 1996, Viscosity structure beneath northeast Iceland: Journa of Geophysical Research, v. 101, p. 17,771-17,793, doi: 10.1029/96JB01074.

Pollitz, F.F., Peltzer, G., and Bürgmann, R., 2000, Mobility of the continental mantle: Evidence from postseismic geodetic observations following the 1992 Landers earthquake: Journal of Geophysical Research, v. 105, p. 8035-8054, doi: 10.1029/1999JB900380.

Pollitz, F.F., Wicks, C., and Thatcher, W., 2001, Mantle flow beneath a continental strike-slip fault: Postseismic deformation after the 1999 Hector Mine earthquake: Science, v. 293, p. 1814-1818, doi: 10.1126/science.1061361.

Poudjom-Djomani, Y.H., Fairhead, J.D., and Griffin, W.L., 1999, The flexural rigidity of Fennoscandia: reflection of the tectonothermal age of the lithospheric mantle: Earth and Planetary Science Letters, v. 174, p. 139-154, doi: 10.1016/ S0012-821X(99)00260-5.

Ranalli, G., 1995, Rheology of the Earth: London, Chapman and Hall, 413 p.

Royden, L., Burchfiel, B.C., King, R.W., Wang, E., Chen, Z., Shen, F., and Liu, Y., 1997, Surface deformation and lower crustal flow in eastern Tibet: Science, 276, p. 788-790, doi: 10.1126/science.276.5313.788.

Sass, J., Blackwell, D., Chapman, D., Costain, J., Decker, E., Lawver, L., and Swanberg, C., 1989, Heat flow from the crust of the United States, in Touloukian, Y.S. Judd, W.R., and Roy, R.F., eds., Physical Properties of Rocks and Minerals, number II-2: New York, Hemisphere Publ. Corp., p. 503-548.

Savage, J.C., and Prescott, W.H., 1978, Asthenospheric readjustment and the earthquake cycle: Journal of Geophysical Research, v. 83, p. 3369-3376, doi: 10.1029/JB083iB07p03369.

Sibson, R.H., 1986, Earthquakes and rock deformation in crustal fault zones: Annual Reviews in Earth and Planetary Science Letters, v. 14, p. 149-175, doi: 10.1146/ annurev.ea.14.050186.001053.

Thatcher, W and Rundle, J.B 1984, A viscoelastic coupling model for the cyclic deformation due to periodically repeated earthquakes at subduction zones: Journal of Geophysical Research, v. 89, p. 7631-7640, doi: 10.1029/ JB089iB09p07631.

Thatcher, W., Matsuda, T., Kato, T., and Rundle, J.B., 1980, Lithospheric loading by the 1896 Riku-u earthquake, northern Japan: Implications for plate flexure and asthenospheric rheology: Journal of Geophysical Research, v. 85, p. 6429-6435, doi: 10.1029/JB085iB11p06429.

Townend, J., and Zoback, M.D., 2000, How faulting keeps the crust strong: Geology, v. 28, p. 399-402, doi: 10.1130/0091-7613(2000)28<399:HFKTCS>2.0.CO;2.

Walcott, R.I., 1970, Flexure of the lithosphere at Hawaii: Tectonophysics, v. 9 p. 435-446, doi: 10.1016/0040-1951(70)90056-9.

Wang, K., 2007, Elastic and viscoelastic models of crustal deformation in subduction earthquake cycles, in Dixon, T. and Moore, J., eds., The seismogenic zone of subduction thrust faults: New York, Columbia University Press, p. 540-575.

Wang, K., and He, J. 1999, Mechanics of low-stress forearc: Nankai and Cascadia: Journal of Geophysical Research, v. 104, p. 15,191-15,205, doi: 10.1029/1999JB900103

Wang, K., Mulder, T., Rogers, G.C., and Hyndman, R.D., 1995, Case for very low coupling stress on the Cascadia subduction fault: Journal of Geophysical Research, 100, p. 12,907-12,918, doi: 10.1029/95JB00516.

Watts, A.B., 1978, An analysis of isostasy in the world's oceans, 1, Hawaiian-Emperor seamount chain: Journal of Geophysical Research, v. 83, p. 5989-6004, doi: 10.1029/JB083iB12p05989.

Watts, A.B., 2001, Isostasy and Flexure of the Lithosphere: Cambridge, Cambridge University Press, $458 \mathrm{p}$.

Watts, A.B., Cochran, J.R., and Selzer, G., 1975, Gravity anomalies and flexure of the lithosphere: a three-dimensional study of the Great Meteor seamount, northeast Atlantic: Journal of Geophysical Research, v. 80, p. 1391-1398, doi: 10.1029/ JB080i011p01391.

Watts, A.B., Rodine, J.H., and Ribe, N.M., 1980, Observations of flexure and the geological evolution of the Pacific Ocean basin: Nature, v. 283, p. 532-537, doi: 10.1038/283532a0

Wilks, K.R., and Carter, N.L., 1990, Rheology of some continental lower crustal rocks: Tectonophysics, v. 182, p. 57-77, doi: 10.1016/0040-1951(90)90342-6.

Zhao, W.-L., and Morgan, W.J., 1985, Uplift of Tibetan plateau: Tectonics, v. 4 p. 359-369, doi: 10.1029/TC004i004p00359

Zhao, W.-L., and Morgan, W.J., 1987, Injection of Indian crust into Tibetan lower crust: Tectonics, v. 6, p. 489-504, doi: 10.1029/TC006i004p00489.

Zoback, M.D., Zoback, M.L., Mount, V.S., Suppe, J., Eaton, J.P., Healy, J.H., Oppenheimer, D., Reasenberg, P., Jones, L., Raleigh, C.B., Wong, I.G. Scotti, O., and Wentworth, C., 1987, New evidence on the state of stress on the San Andreas fault system: Science, v. 238, p. 1105-1111, doi: 10.1126/ science. 238.4830.1105.

Manuscript received 9 November 2007; accepted 11 February 2008. $\diamond$

\section{GSA ANNOUNCES NEW JOURNAL}

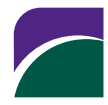

THE GEOLOGICAL SOCIETY OF AMERICA ${ }^{\circledast}$

\section{Litbosphere}

The Geological Society of America is pleased to announce Lithosphere, a monthly journal to be launched in early 2009. For more information, go to p. 78 .

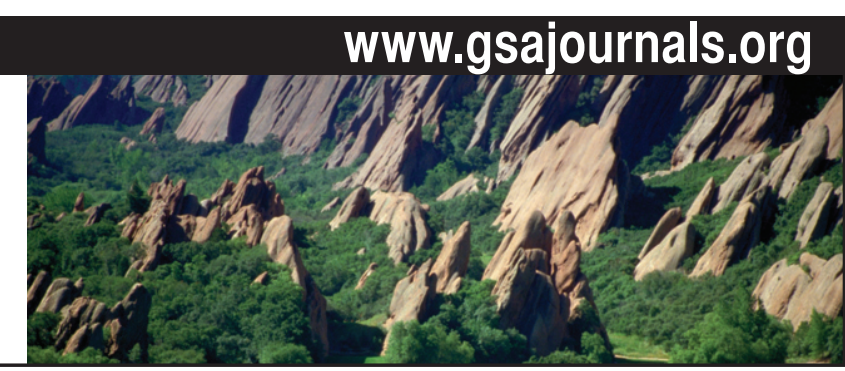

Arrowhead Golf Course southwest of Denver. Photo by Richard Grant. Denver Metro Convention \& Visitors Bureau. 